\title{
HUBUNGAN KUALITAS TIDUR DAN POLA MAKAN (DIET DASH) DENGAN KEJADIAN PENYAKIT HIPERTENSI PADA USIA DEWASA MUDA DI PUSKESMAS SIMBARWARINGIN KECAMATAN TRIMURJO KABUPATEN LAMPUNG TENGAH PROVINSI LAMPUNG
}

\author{
Shelly Novitri ${ }^{1}$, Toni Prasetya ${ }^{2}$, Ika Artini ${ }^{3}$ \\ ${ }^{1}$ Program Studi Kedokteran Fakultas Kedokteran Universitas Malahayati \\ 2Departemen Ilmu Penyakit Dalam Rumah Sakit Pertamina Bintang Amin Lampung \\ ${ }^{3}$ Departemen Farmakologi Fakultas Kedokteran Universitas Malahayati
}

[email korespondensi: shellynovitri11@gmail.com]

\begin{abstract}
Relationship of Quality of Sleep And Diet Patterns (Diet Dash) With Hypertension Incidence in Young Adults at Simbarwaringin Puskesmas Simbarwaringin District Trimurjo District Lampung Tengah Lampung Province. Hypertension causes about 8 million deaths each year, of which 1.5 million die in Southeast Asia, where a third of the population suffers from hypertension, which can add to the burden of medical expenses. Diet is very related to the frequency and type of food we consume and it turns out that changes in one's diet are very inseparable from one of the problems of hypertension. Redline also said that cardiologists should pay more attention to patients with difficulty sleeping or difficulty resting, because sleep disorders are one of the factors that can cause an increase in blood pressure in adults, children and adolescents. The aim of this study was to know the relationship of sleep quality and diet (diet dash) with the incidence of hypertension disease in young adulthood in Puskesmas Simbarwaringin Trimurjo subdistrict, Central Lampung Regency, Lampung Province. The type of research used in this study is observational analytics. Sampling method used in this study is sampling technique in the study using accidental sampling on respondents in Puskesmas Simbarwaringin Trimurjo District, Central Lampung Province. There were 58 respondents in the study. Results from research conducted at Puskesmas Simbarwaringin, Trimurjo Subdistrict, Central Lampung Regency, Lampung Province showed there is a significant correlation between the quality of sleep patterns and the incidence of hypertension ( $p$ value $=0.518$ ) and there is a significant unidirectional correlation between dietary factors (diet dash) and the incidence of hypertension (data correlation value is 0.601 ). Poor sleep patterns can increase the risk of high blood pressure and diet (diet dash) if not routinely undergoing it then the risk of hypertension is still there.
\end{abstract}

Keywords: Hypertension, Sleep Patterns, Diet Patterns

\begin{abstract}
Abstrak: Hubungan Kualitas Tidur dan Pola Makan (Diet Dash) dengan Kejadian Penyakit Hipertensi pada Usia Dewasa Muda di Puskesmas Simbarwaringin Kecamatan Trimurjo Kabupaten Lampung Tengah Provinsi Lampung. Hipertensi menyebabkan sekitar 8 juta kematian setiap tahun, di mana 1,5 juta meninggal di Asia Tenggara, di mana sepertiga penduduknya menderita hipertensi, yang dapat menambah beban biaya pengobatan. Pola makan sangat berkaitan dengan frekuensi dan jenis makanan yang kita konsumsi dan ternyata perubahan pola makan seseorang sangat tidak lepas dari salah satu masalah hipertensi. Redline juga mengatakan, ahli jantung harus lebih memperhatikan pasien dengan kesulitan tidur atau kesulitan istirahat, karena gangguan tidur merupakan salah satu faktor yang dapat menyebabkan peningkatan tekanan darah pada orang dewasa, anak-anak dan remaja. Tujuan penelitian ini untuk mengetahui hubungan kualitas tidur dan pola makan (diet dash) dengan kejadian penyakit hipertensi pada usia dewasa muda di Puskesmas Simbarwaringin kecamatan
\end{abstract}


Trimurjo, Kabupaten Lampung Tengah, Provinsi Lampung. Jenis penelitian yang digunakan dalam penelitian ini adalah analitik observasional. Metode sampling yang digunakan pada penelitian ini adalah teknik pengambilan sampel pada penelitian menggunakan accidental sampling pada responden di Puskesmas Simbarwaringin Kecamatan Trimurjo Kabupaten Lampung Tengah Provinsi Lampung. Terdapat 58 orang responden dalam penelitian ini. Hasil dari penelitian yang dilakukan di Puskesmas Simbarwaringin, Kecamatan Trimurjo, Kabupaten Lampung Tengah Provinsi Lampung menunjukan ada korelasi yang signifikan antara kualitas pola tidur dengan kejadian hipertensi ( $p$ value $=0.518$ ) dan ada korelasi searah yang signifikan antara faktor pola makan (diet dash) dengan kejadian hipertensi (nilai korelasi data yaitu 0.601). Pola tidur yang buruk dapat meningkatkan resiko tekanan darah tinggi dan pola makan (diet dash) apabila tidak rutin menjalaninya maka resiko hipertensi masih ada.

Kata Kunci: Hipertensi, Pola Tidur, Pola Makan

\section{PENDAHULUAN}

Menurut

Organization (WHO), penyakit hipertensi adalah suatu keadaan dimana tekanan darah seseorang melebihi tekanan darah normal yaitu $140 \mathrm{mmHg}$ pada sistolik dan $90 \mathrm{mmHg}$ pada diastolic (Srirawinda dkk, 2018). informasi ini di dapatkan dari (WHO) 2015, menunjukan sekitar 1,13 miliar orang di dunia menderita hipertensi. Diperkirakan pada 2025 akan ada 1,5 miliar orang yang sudah mengalami hipertensi. Setiap tahun ada 9,4 juta orang meninggal akibat hipertensi dan komplikasinya (Srirawinda dkk, 2018).

$$
\text { Menurut data Organisasi }
$$

Kesehatan Dunia, pada 2015, sekitar 8 miliar orang di seluruh dunia meninggal karena tekanan darah tinggi setiap tahun, dan sekitar 1,5 juta orang di Asia Tenggara meninggal karena tekanan darah tinggi setiap tahun. Lebih dari separuh orang dewasa di Asia Timur dan Asia Selatan menderita tekanan darah tinggi. Prevalensi hipertensi akan terus meningkat tajam, dan diperkirakan 29\% orang dewasa akan menderita penyakit ini pada tahun 2015. Hipertensi menyebabkan sekitar 8 juta kematian setiap tahun, di mana 1,5 juta meninggal di Asia Tenggara, di mana sepertiga penduduknya menderita hipertensi, yang dapat menambah beban biaya pengobatan (Kemenkes, 2017).

Menurut data yang diambil dari Riskesdas 2018 penyakit tidak menular ini terus meningkat jika dibandingkan dengan data dari Riskesdas pada tahun 2013 . Salah satu penyakit tidak menular yang selalu meningkat di setiap tahun nya adalah hipertensi. Dijelaskan juga dari Badan Penelitian dan Pengembangan Kesehatan berdasarkan dari hasil pengukuran tekanan darah, jumlah hipertensi meningkat yang awalnya hanya $25,8 \%$ menjadi $34,1 \%$ di tahun 2018 (Depkes, 2019).

Di Provinsi Lampung pada tahun 2016 hipertensi mendapati peringkat urutan ke 4 dari 10 besar kasus penyakit dengan diagnosa terbanyak di Lampung. kunjungan pasien dengan hipertensi pun rata rata per tahun mencapai 100 pasien di salah satu rumah sakit bandar lampung yaitu Rumah Sakit Umum Daerah Dr.H.Abdul Moeloek (RSUDAM) (Kemenkes, 2017).

Berdasarkan survey awal yang dilakukan, Puskesmas Simbarwaringin Kecamatan Trimurjo, Lampung Tengah, hipertensi menempati posisi penyakit dengan diagnosa terbanyak kedua, dengan jumlah pasien hipertensi tahun 2017 sebanyak 1.065 pasien, sedangkan pada tahun 2018 meningkat menjadi 1.174 pasien. Tingginya kejadian hipertensi di Puskesmas Simbarwaringin yang semakin tahun semakin meningkat, namun belum ada penelitian terkait hubungan antara pola tidur dan pola makan berdasarkan diet dash dengan kejadian penyakit hipertensi dewasa muda.

Salah satu cara menurunkan tekanan darah dan menurunkan resiko permasalahan kardiovaskular adalah 
dengan menjalankan pola hidup sehat selama empat sampai enam bulan. Penurunan berat badan, mengurangi asupan garam, olahraga, istirahat yang cukup, dan berhenti merokok adalah beberapa pola hidup sehat yang dianjurkan (Dipiro et al, 2011).

Pola makan sangat berkaitan dengan frekuensi dan jenis makanan yang kita konsumsi dan ternyata perubahan pola makan seseorang sangat tidak lepas dari salah satu masalah hipertensi. Jika porsi dari makanan yang berlebih maka kita akan mengalami obesitas yang merupakan salah satu faktor munculnya infeksi . selain itu ternyata asupan garam yang berlebihan pun akan mengakibatkan hipertensi (Suyono, 2001). Pengetahuan masyarakat tentang perbaikan pola makan masih sangat minim. Redline mengatakan, ahli jantung harus lebih memperhatikan pasien dengan kesulitan tidur atau kesulitan istirahat, karena gangguan tidur merupakan salah satu faktor yang dapat menyebabkan peningkatan tekanan darah pada orang dewasa, anak-anak dan remaja. Kualitas tidurlah yang dapat mempengaruhi proses kondisi-mapan. Jika proses ini terganggu, dapat menjadi faktor yang meningkatkan risiko penyakit kardiovaskular. Selain perubahan gaya hidup (pola makan dan lingkungan olahraga), kualitas tidur juga sangat penting untuk menjaga kesehatan (Andreas, 2011).

"Modern Health World" sudah mengenal istilah "Good Health Triumvirate" yang artinya tiga komponen utama kesehatan. Ketiganya adalah kesehatan yang baik, keseimbangan nutrisi dan kualitas tidur. Jika hanya menjaga pola makan dan olahraga saja tidak cukup, maka kesehatan dan kualitas hidup manusia juga sangat erat kaitannya dengan kualitas tidur. Oleh karena itu dengan memperbaiki pola tidur maka kualitas hidup dan kesehatan dapat ditingkatkan (Dement, 2010).

Kualitas tidur mengacu pada indikator subjektif dari gaya tidurnya, termasuk perasaan istirahat dan kepuasan tidurnya ketika bangun (Dewald et al, 2010). Siklus seseorang adalah 24 jam siang dan malam, juga dikenal sebagai ritme sirkadian. Padahal, hal ini justru akan mempengaruhi kualitas tidur seseorang. Jika ritme sirkadian seseorang lebih stabil dan konsisten, hal tersebut dapat meningkatkan kualitas tidur (Breus, 2015).

\section{METODE}

Jenis penelitian yang digunakan dalam penelitian ini adalah analitik observasional. Metode sampling yang digunakan pada penelitian ini adalah Teknik pengambilan sampel pada penelitian menggunakan accidental sampling pada responden di Puskesmas Simbarwaringin Kecamatan Trimurjo Kabupaten Lampung Tengah Provinsi Lampung. Terdapat 58 orang responden dalam penelitian ini

Kriteria Inklusi

1) Bersedia menjadi responden

2) $21-40$ tahun

3) Wanita \& Pria

4) Indeks masa tubuh normal

Kriteria Eksklusi

1) Riwayat penyakit myocardial infarction

2) Riwayat penyakit gagal jantung kongestif

3) Sedang menggunakan obat antihypertensive

4) Sedang menggunakan obat anti depresi 
HASIL

Karakteristik Responden

1. Rerata Usia Responden di Puskesmas Simbarwaringin kecamatan Trimurjo, Kabupaten Lampung Tengah, Provinsi Lampung Tahun 2020

Tabel 1. Karakteristik Subjek Penelitian Berdasarkan Usia

\begin{tabular}{llllll}
\hline Karakteristik & $\mathrm{N}$ & Min & Maks & Mean & $\begin{array}{l}\text { Standar } \\
\text { Deviasi }\end{array}$ \\
\hline Usia (Tahun) & 58 & 27 & 40 & 35.90 & 3.88
\end{tabular}

Berdasarkan tabel 1 menunjukkan dengan usia termuda 27 tahun dan bahwa sampel berjumlah 58 responden, tertua 40 tahun. memiliki rata-rata usia 35.90 tahun

\section{Distribusi Frekuensi Responden Berdasarkan Jenis Kelamin}

Tabel 2. Distribusi Frekuensi Responden Berdasarkan Jenis Kelamin

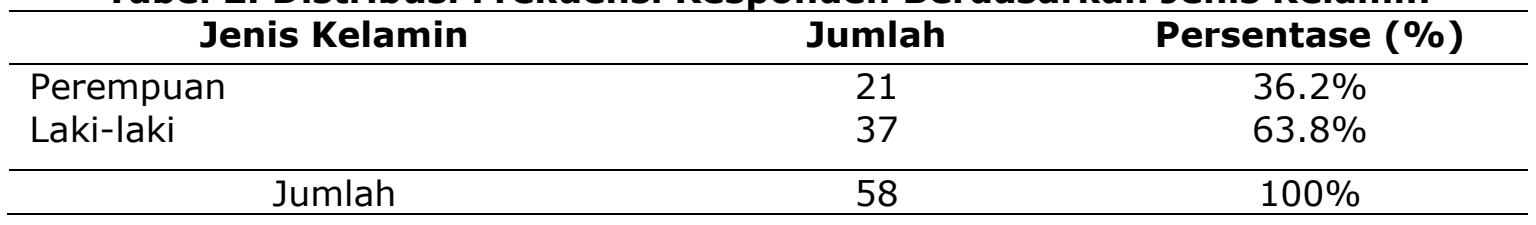

Dari tabel 2 di atas dapat dilihat

sebanyak 21 orang $(36.2 \%)$ dan lakiresponden berjenis kelamin perempuan

laki sebanyak 37 orang (63.8\%).

\section{Analisa Univariat}

1. Pola Tidur

Tabel 3. Distribusi Frekuensi Responden Berdasarkan Pola Tidur

\begin{tabular}{|c|c|c|}
\hline Pola Tidur & Frekuensi & Persentasi (\%) \\
\hline$<8$ jsm & 35 & $60.3 \%$ \\
\hline$\geq 8 \mathrm{Jam}$ & 23 & $39.7 \%$ \\
\hline Total & 58 & $100 \%$ \\
\hline
\end{tabular}

Dari tabel 3 di atas dapat dilihat 35 orang (60.3\%) dan $\geq 8$ jam pola tidur responden $<8$ jam sebanyak sebanyak 23 orang $(39.7 \%)$.

\section{Pola Makan}

Tabel 4. Distribusi Frekuensi Responden Berdasarkan Pola Makan

\begin{tabular}{|c|c|c|}
\hline Pola Makan & Frekuensi & Persentasi (\%) \\
\hline Tidak sesuai & 39 & $67.2 \%$ \\
\hline Sesuai & 19 & $32.8 \%$ \\
\hline Total & 58 & $100 \%$ \\
\hline
\end{tabular}

Dari tabel 4 di atas dapat dilihat responden yang memiliki pola makan

$(67.2 \%)$ dan pola makan sesuai tidak sesuai sebanyak 39 orang 


\section{Kejadian Hipertensi}

Tabel 5. Distribusi Frekuensi Responden Berdasarkan Kejadian Hipertensi

\begin{tabular}{lccc}
\hline \multicolumn{1}{c}{ Kejadian Hipertensi } & Frekuensi & Persentasi (\%) \\
\hline Derajat 1 & 37 & $63.8 \%$ \\
Derajat 2 & 21 & $36.2 \%$ \\
\hline & Total & 58 & $100 \%$ \\
\hline
\end{tabular}

Dari tabel 5 di atas dapat dilihat responden yang mengalami kejadian hipertensi derajat 1 sebanyak 37 orang
$(63.8 \%)$ dan derajat 2 sebanyak 21 orang $(36.2 \%)$.

\section{Analisis Bivariat}

1. Hubungan Pola Tidur Dengan Kejadian Hipertensi

Tabel 6. Analisis Hubungan Pola Tidur dengan Kejadian Hipertensi di Puskesmas Simbarwaringin Kecamatan Trimurjo, Kabupaten Lampung Tengah, Provinsi Lampung Tahun 2020

\begin{tabular}{|c|c|c|c|c|c|c|c|c|}
\hline \multirow{3}{*}{ Pola Tidur } & \multicolumn{4}{|c|}{ Hipertensi } & \multirow{3}{*}{ Total } & \multirow{3}{*}{$\%$} & \multirow{3}{*}{$\begin{array}{c}\mathrm{p}- \\
\text { value }\end{array}$} & \multirow{3}{*}{$\begin{array}{l}\text { OR (CI } \\
95 \%)\end{array}$} \\
\hline & \multicolumn{2}{|c|}{ Derajat 1} & \multicolumn{2}{|c|}{ Derajat 2} & & & & \\
\hline & $\mathrm{n}$ & $\%$ & $\mathrm{n}$ & $\%$ & & & & \\
\hline$<8$ jam & 16 & 45.7 & 19 & 54.3 & 35 & 100 & & \\
\hline$\geq 8$ jam & 21 & 91.3 & 2 & 8.7 & 23 & 100 & 0.000 & $12.46(2.52-$ \\
\hline Total & 37 & 63.8 & 21 & 36.2 & 58 & 100 & & \\
\hline
\end{tabular}

Berdasarkan tabel 6 di atas, dari 35 responden yang memiliki pola tidur $<8$ jam sebanyak 16 orang (45.7\%) mengalami hipertensi derajat 1 dan 19 orang $(54.3 \%)$ mengalami hipertensi derajat 2. Sedangkan dari 23 responden yang memiliki pola tidur $\geq 8$ jam sebanyak 21 orang $(9.3 \%)$ mengalami hipertensi derajat 1 dan 2 orang (8.7\%) mengalami hipertensi derajat 2 .

Dengan menggunakan uji Chi Square menunjukkan p-value $=0.000$ dimana kurang dari nilai kemaknaan yaitu 5\% (0.05), hal tersebut menunjukkan terdapat hubungan yang signifikan antara pola tidur dengan kejadian hipertensi. Dari analisis di atas didapatkan nilai $\mathrm{OR}=12.46$ yang menyatakan bahwa responden yang memiliki pola tidur $<8$ jam berisiko 12.46 kali untuk mengalami hipertensi. Dari analisis diatas didapatkan nilai CI $95 \% \quad(2.52 \quad-\quad 61.48 \%$ ) yang menyatakan bahwa responden yang memiliki pola tidur <8 jam sekurang kurangnya lebih beresiko sebesar 2,52 kali lipat untuk mengalami hipertensi dan paling besar lebih beresiko sebesar 61,48 kali lipat untuk mengalami hipertensi. 
Tabel 7. Analisis Hubungan Pola Makan Dengan Kejadian Hipertensi di Puskesmas Simbarwaringin Kecamatan Trimurjo, Kabupaten Lampung Tengah, Provinsi Lampung Tahun 2020

\begin{tabular}{|c|c|c|c|c|c|c|c|c|}
\hline \multirow{3}{*}{ Pola Makan } & \multicolumn{4}{|c|}{ HIpertensi } & \multirow{3}{*}{ Total } & \multirow{3}{*}{$\%$} & \multirow{3}{*}{$\begin{array}{c}\mathrm{p}- \\
\text { value }\end{array}$} & \multirow{3}{*}{ OR (CI 95\%) } \\
\hline & \multicolumn{2}{|c|}{ Derajat 1} & \multicolumn{2}{|c|}{ Derajat 2} & & & & \\
\hline & $\mathrm{n}$ & $\%$ & $\mathrm{n}$ & $\%$ & & & & \\
\hline Tidak sesuai & 21 & 53.8 & 18 & 46.2 & 39 & 100 & & \\
\hline Sesuai & 16 & 84.2 & 3 & 15.8 & 19 & 100 & 0.024 & $\begin{array}{c}4.5 /(1.14- \\
18.25)\end{array}$ \\
\hline Total & 37 & 63.8 & 21 & 36.2 & 58 & 100 & & \\
\hline
\end{tabular}

Berdasarkan tabel 7 di atas, dari 39 responden yang memiliki pola makan tidak sesuai sebanyak 21 orang (53.8\%) mengalami hipertensi derajat 1 dan 18 orang $(46.2 \%)$ mengalami hipertensi derajat 2. Sedangkan dari 19 responden yang memiliki pola makan sesuai sebanyak 16 orang $(84.2 \%)$ mengalami hipertensi derajat 1 dan 3 orang $(15.8 \%)$ mengalami hipertensi derajat 2.

Dengan menggunakan uji Chi Square menunjukkan p-value $=0.024$ dimana kurang dari nilai kemaknaan yaitu $5 \%(0.05)$, hal tersebut menunjukkan terdapat hubungan yang signifikan antara pola makan dengan kejadian hipertensi. Dari analisis di atas didapatkan nilai $\mathrm{OR}=4.57$ yang menyatakan bahwa responden yang memiliki pola makan tidak sesuai berisiko 4.57 kali untuk mengalami hipertensi. Dari analisis diatas didapatkan nilai CI 95\% ( 1.14 - 18.25) yang menyatakan bahwa responden yang memiliki pola makan tidak sesuai sekurang kurangnya lebih beresiko sebesar 1.14 kali lipat untuk mengalami hipertensi dan paling besar lebih beresiko sebesar 18,25 kali lipat untuk mengalami hipertensi.

\section{PEMBAHASAN \\ Hubungan Pola Tidur Dengan Kejadian Hipertensi di Puskesmas Simbarwaringin kecamatan Trimurjo, Kabupaten Lampung Tengah, provinsi Lampung tahun 2020.}

Dari hasil penelitian di atas diperoleh hasil analisis antara hubungan pola tidur dengan kejadian hipertensi dengan nilai $p$-value $=0.000$. Hal ini menunjukkan bahwa ada hubungan yang signifikan antara pola tidur dengan kejadian hipertensi dan juga menampilkan nilai $\mathrm{OR}=12.46$. Hal ini membuktikan bahwa responden yang memiliki pola tidur tidak baik berisiko terjadinya hipertensi sebesar 12.46 kali. Hasil penelitian ini sejalan dengan penelitian Melizza, dkk (2020) terhadap pasien hipertensi di wilayah kerja Puskesmas Ciptomulya dimana dari hasil penelitian diperoleh nilai $p$ value $=0.040$.

Penelitian oleh Melizza, dkk (2020) menyatakan kualitas tidur yang buruk atau tidak mencukupi $\geq 7$ jam/ malam pada seseorang berhubungan dengan peningkatan tekanan darah. Selain itu Liu et al (2016) juga menjelaskan bahwa prevalensi pada orang yang hipertensi menunjukan kualitas tidur yang buruk yaitu sebanyak $(69,74 \%)$.

Hasil penelitian ini menyatakan kualitas tidur pasien hipertensi didapatkan sebagian besar pada kualitas tidur yang buruk dan terbukti berkaitan dengan meningkatnya tekanan darah, sebagaimana teori yang dikemukakan oleh Liu et al (2016) menyatakah bahwa sebagian besar gangguan tidur dialami oleh penderita hipertensi dibandingkan seseorang yang memiliki tekanan darah normal, hal tersebut dipengaruhi saat tidur terjadi peningkatan aktivitas saraf 
simpatik terhadap pembuluh darah yang meningkatkan detak jantung dan terjadinya peningkatan tekanan darah. Selain itu tidur yang tidak normal, mengalami masalah dan kebiasaan tidur dapat menjadikan stres fisik, psikososial dan peningkatan aktivitas saraf simpatik sehingga meningkatkan detak jantung dan tekanan darah serta retensi garam yang dapat menjadikan hipertensi. Hipertensi dapat disebabkan oleh banyak faktor yang salah satu faktornya adalah kualitas tidur, apabila seseorang mengalami kualitas yang buruk maka dapat meningkatkan aktivitas saraf simpatik sehingga terjadi peningkatan detak jantung yang menyebabkan meningkatnya tekanan darah. Definisi keakuratan dari hasil penelitian ini mengapa CI melebar yaitu besar kecilnya jarak antara lower dan upper terutama ditentukan oleh jumlah sampel yang artinya semakin banyak sampel yg digunakan semakin tinggi tingkat kepercayaannya.

\section{Hubungan Pola Makan Dengan Kejadian Hipertensi di Puskesmas Simbarwaringin Trimurjo, Kabupaten Lampung Tengah, provinsi Lampung tahun 2020.}

Dari hasil penelitian di atas diperoleh hasil analisis antara hubungan pola makan dengan kejadian hipertensi dengan nilai $p$-value $=0.024$. Hal ini menunjukkan bahwa ada hubungan yang signifikan antara pola makan dengan kejadian hipertensi. dan juga menampilkan nilai $\mathrm{OR}=4.57$. Hal ini membuktikan bahwa responden yang memiliki pola tidur tidak baik berisiko terjadinya hipertensi sebesar 4.57 kali. Hasil penelitian di atas sejalan dengan penelitian Sitorus (2019) dimana dari hasil uji statistik diperoleh hasil terdapat hubungan yang bermakna antara asupan lemak dengan kejadian hipertensi ( $p$ value $=0.001$ )

Hasil penelitian ini juga sejalan dengan dengan penelitian Mahmudah (2015) ada hubungan signifikan antara asupan lemak dengan hipertensi dengan nilai $p$ value $0,008(<0,05)$. Penelitian lain yang juga sejalan dengan penelitian Arza dan Yenni (2012) bahwa terdapat hubungan konsumsi lemak dengan kejadian hipertensi pada orang dewasa di wilayah kerja Puskesmas Simpang Empat Kecamatan Pasaman Kabupaten Pasaman Barat dengan nilai signifikansi sebesar 0,001 $(p<0,0)$. Hasil penelitian ini sesuai dengan pernyataan Ilham, dkk (2019) yang mengatakan pola makan yang salah dapat menyebabkan peningkatan tekanan darah seperti kebiasaan mengkonsumsi makanan berlemak terutama pada asupan lemak jenuh dan kolesterol.

Pernyataan di atas didukung oleh penelitian ini didukung juga oleh Bertalina dan Muliani (2016) yang menyatakan ada hubungan antara asupan natrium dengan kejadian hipertensi. Penelitian ini juga sejalan dengan penelitian Muliyati dkk (2011) yang mengatakan bahwa terdapat hubungan antara natrium dengan kejadian hipertensi pada pasien rawat jalan di RSUP Dr. Wahidin Sudirohusodo Makassar. Konsumsi serat yang dibutuhkan oleh tubuh sebesar 25 gram per hari dapat juga menekan terjadinya hipertensi pada seseorang. Asupan tinggi serat terutama dalam bentuk serat larut berkaitan dengan pencegahan hipertensi.Apabila asupan serat rendah, maka dapat menyebabkan obesitas yang berdampak pada peningkatan tekanan darah dan penyakit degeneratif (Almatsier, 2009). Penelitian ini berbanding lurus dengan penelitian Widyaningrum (2014) menyatakan bahwa konsumsi serat terbukti memiliki pengaruh dengan kejadian hipertensi pada responden di UPT Pelayanan Sosial Lanjut Usia Jember. Serat pangan dapat membantu meningkatkan pengeluaran kolesterol melalui feses dengan jalan meningkatkan waktu transit bahan makanan melalui usus kecil. Selain itu, konsumsi serat sayuran dan buah akan mempercepat rasa kenyang. Keadaan ini menguntungkan karena dapat mengurangi pemasukan energi dan obesitas, dan akhirnya akan menurunkan risiko hipertensi. Definisi keakuratan dari hasil penelitian ini 
mengapa CI melebar yaitu besar kecilnya jarak antara lower dan upper terutama ditentukan oleh jumlah sampel yang artinya semakin banyak sampel yg digunakan semakin tinggi tingkat kepercayaannya.

\section{KESIMPULAN}

Berdasarkan penelitian yang telah dilakukan, maka dapat disimpulkan bahwa sebagian besar pola tidur responden $<8$ jam sebanyak 35 orang $(60.3 \%)$, sebagian besar pola makan tidak sesuai sebanyak 39 orang $(67.2 \%)$, dan sebagian besar responden mengalami hipertensi derajat 1 sebanyak 37 orang $(63.8 \%)$.

Dapat disimpulkan pula bahwa ada hubungan yang baik antara pola tidur dengan kejadian hipertensi dengan diperoleh nilai $\mathrm{p}$-value $=0.000$ dan OR $=$ 12.46 dan ada hubungan yang baik antara pola tidur dengan kejadian hipertensi dengan diperoleh nilai $p$ value $=0.024$ dan $\mathrm{OR}=4.57$

\section{Saran}

Dapat menambah studi kepustakaan terutama yang berkaitan dengan Penyakit Tidak Menular (PTM) tentang hipertensi dan diharapkan menjadi masukan yang bermanfaat bagi mahasiswa Prodi Kedokteran Umum Fakultas kedokteran.

Bagi masyarakat/ penderita hipertensi agar lebih memperhatikan faktor-faktor yang dapat meningkatkan derajat keparahan hipertensi dan lebih mengatur pola hidup yang baik serta melakukan check-up secara berkala di Puskesmas. Selain itu penderita hipertensi diwajibkan memperbaiki pola tidur (minimal tidur \pm 8 jam / hari dan pola makan dengan mengurangi konsumsi makanan yang dapat menjadi pencetus timbulnya hipertensi.

Diharapkan untuk lebih menggali faktor-faktor lain penyebab terjadinya hipertensi sehingga didapatkan hasil yang lebih sempurna dan juga melibatkan lebih banyak penggunaan sampel penelitian.

\section{DAFTAR PUSTAKA}

Almatsier. (2009). Prinsip Dasar IImu Gizi. Jakarta: PT. Gramedia Pustaka.

Arza, P.A. dan Novi, Y. (2012). FaktorFaktor yang Berhubungan dengan Kejadian Hipertensi pada Orang Dewasa di Wilayah Kerja UPTDK Puskesmas Simpang Empat Kecamatan Pasaman Kabupaten Pasaman Barat Tahun 2012. LPPM STIKES YARSI.

Bertalina dan Muliani. (2016). Hubungan Pola Makan, Asupan Makanan Dan Obesitas Sentraldengan Hipertensi Di Puskesmas Rajabasa Indah Bandar Lampung. Jurnal Kesehatan 7(1).

Breus, M.J. (2015). Sleep Hygiene Solutions for Better Sleep. Available from: http://www.webmd.com/sleepdisorders/features/sleep-hygiene

Dement, W.C. (2010). Sleep Apnea Management Service for Payers, Doctors, and Their Patients.

Depkes. (2019). Pusat Data dan Informasi Kementerian Kesehatan RI.

http://www.depkes.go.id/article/vi ew/19051700002/hipertensipenyakit-paling-banyak-diidapmasyarakat.html

Dewald, J.F., Anne, M.M., Frans, J.O., Gerard, A.K., and Susan, M.B. (2010). The Influence of Sleep Quality, Sleep Duration and Sleepiness on Scholl Performance in Children and Adolescents: A Meta-Analytic Review. Sleep Medicine Review 14(2010); 179189.

Dipiro, J.T., Robert, L.T., Gary, C.Y. Gary, R.M., Barbara, G.W., and L.M.P. (2011). Pharmacotherapy: A Pathophysiologic Approach, 8th ed. United State of America: Mc Graw Hill.

Ilham, D., Harleni, dan Siska, R.M. (2019). Hubungan Status Gizi dan Riwayat Keluarga dengan Kejadian Hipertensi pada Lansia di Puskesmas Lubuk Buaya Padang. 
Prosiding Seminar Kesehatan

Perintis 2(1).

Kemenkes. (2017). Profil Kesehatan Provinsi Lampung 2016. http://www.depkes.go.id/resource s/download/profil/PROFIL_KES_PR OVINSI_2016/08_Lampung_2016. pdf diaksestahun 2016

Liu, R., Qian, Z., Trevathan, E., Chang, J., Zelicoff, A., Hao, Y., \& Lin, S. (2016). Poor Sleep Quality Associated with High Risk of Hypertension and Elevated Blood Pressure in China : Results From A Large Population-Based Study. Hypertension Research 39(1): 54-59. https://doi.org/10.1038/hr.2015.9 8

Mahmudah, S., Taufik, M., Firlia, A.A., dan Ibnu, M. (2015). Hubungan Gaya Hidup Dan Pola Makan Dengan Kejadian Hipertensi Pada Lansia Di Kelurahan Sawangan Baru Kota Depok Tahun 2015. Jurnal Biomedik 7(2).

Melizza, N., Nurul, H., Anggraini, D.K., Nur, L.M., Cici, I.S., Yoyok, B.P. (2020). Hubungan Kualitas Tidur Dengan Tekanan Darah Pada Pasien Hipertensi Di Wilayah Kerja Puskesmas Ciptomulyo. CHMK Nursing Scientific Journal 4(2).

Muliyati, H., Aminuddin, S., dan Saifuddin, S. (2011). Hubungan Pola Konsumsi Natrium dan Kalium serta Aktivitas Fisik dengan Kejadian Hipertensi pada Pasien Rawat Jalan di RSUP Dr. Wahidin Sudirohusodo Makassar. Media Gizi Kesehatan Masyarakat $1(1): 46-51$.

Sitorus, J. (2019). Pengaruh Pola Makan dan Aktivitas Fisik Terhadap Kejadian Hipertensi pada Pasien Rawat Jalan di RSU HKBP Balige. Jurnal IImiah Kebidanan IMELDA 5(1):628-638.

Srirawinda, Firdaus, J.K., dan Eka, P.H.B. (2018). Hubungan Perilaku Merokok dan Pola Konsumsi Kopi dengan Terjadinya Hipertensi di Puskesmas Momunu Kabupaten Buol. Jurnal Kolaboratif Sains 1(1).
Suyono, S. (2001). Buku Ajar ilmu Penyakit Dalam Jilid II. Jakarta: Balai Penerbit FKUI.

Widyaningrum, A.T. (2014). Hubungan Asupan Natrium, Kalium, Magnesium Dan Status Gizi Dengan Tekanan Darah Pada Lansia Di Kalurahan Makamhaji Kecamatan Kartasura. [Naskah Publikasi]. Surakarta: Fakultas Ilmu Kesehatan Universitas Muhammadiyah Surakarta. 